\title{
Editorial
}

\section{The role of occupational health services in the universal halth coverage era in Indonesia}

\author{
Muchtaruddin Mansyur*,** \\ *Occupational Medicine Division, Faculty of Medicine Universitas Indonesia \\ **Southeast Asian Ministers of Education Regional Center for Food and Nutrition \\ (SEAMEO-RECFON)
}

In accordance to Act No 24 of the year 2011 on the Social Security Administrating Body, the Indonesian National Social Security program is managed by two national organizations, namely: Social Security Health Agency (Badan Penyelenggara Jaminan Sosial Kesehatan = BPJS Kesehatan) and Social Security Administering Body on Employment (Badan Penyelenggara Jaminan Sosial Ketenaga kerjaan $=$ BPJS Ketenagakerjaan $)$. The BPJS Kesehatan is responsible for providing health coverage for all Indonesians through the National Social Health Insurance Scheme known as the Jaminan Kesehatan Nasional/JKN. The BPJS Ketenagakerjaan is responsible for providing the worker's social security consisting of Provident Fund Benefit, Accident Benefit, Pension Benefit, and Death Benefit. ${ }^{(1)}$

The Indonesian government has been continuously improving the health service program towards better national universal health coverage and has set the 2019 functional achievement target of $95 \%$ of the population enrolled in the program. To ensure that this target of the program will be achieved, the government pays the premium of BPJS Kesehatan of the poor and near poor. ${ }^{(2)}$

However, BPJS Kesehatan has been facing a financial problem since the first year of operation due mainly to the discrepancy between the expenditure and the collected membership premium. The expenditure of healthcare cost they paid to the healthcare facilities was much higher than the funding they collected from the membership premium, and the compliance rate of the members in regular premium paying was not good enough. In addition, around ten to twelve million members did not pay their premium regularly. The BPJS claimed that their potential financial deficit for the fiscal year 2018 projected up to IDR 16.5 billion including the 2017 carryover of the financial deficit. ${ }^{(3)}$ In contrast, the BPJS Ketenagakerjaan has shown a more stable financial standing with a surplus of IDR 1,299,524 million in 2017. ${ }^{(4)}$ This does not mean, however, that the BPJS Ketenagakerjaan has been successful in providing the National Workers Social Security as their responsibility to assure the eligible workers to get the benefit of occupational diseases compensation is still less. The compensated cases of occupational diseases were far below of the expected total number of occupational disease cases in Indonesia. This means that BPJS Kesehatan has been paying much unnecessary health care service cost due to underdiagnosed occupational diseases. The majority of Indonesian physicians do not pay any attention to the diagnosis of occupational diseases, and there is also no regulation to allow for transfer of the occupational diseases care funding responsibility 
from the BPJS Kesehatan to the BPJS Ketenagakerjaan nor is there a clear responsibility transfer procedure of handing over the occupational diseases management costs from the former to the latter organization.

The continuous deficit of the BPJS Kesehatan is not surprising for many health insurance experts as there are some principal policies that have not been implemented consistently. Moreover, the medical care cost went to the curing and treatment for some cases of chronic disease, malignancy, and terminal disease. The Indonesian Global Burden Disease Study 2016 found that the leading causes of disability-adjusted life-years (DALYs) in 2016 are the six non-communicable diseases (NCDs) comprising ischemic heart attack, cerebrovascular diseases, diabetes, low back and neck pain, sense organ diseases, and road injuries. These are the common prevalent cases among the working age group. Furthermore, occupational risk is one of the ten leading risk factors for premature mortality. ${ }^{(5)}$ The data of the high rank of the occupational risk for premature mortality supports the assumption of potential unnecessary financial load of BPJS Kesehatan due to under-diagnosed occupational disease. In addition the data of NCDs burden also supports the opinion that implementing the comprehensive health care approach is an urgent matter in the era of universal health coverage and national social security. The target of making the comprehensive health care approach into a universal coverage program is not only to improve health care services but also to solve public health problem issues, including the equity and efficiency of the health services, which are strongly correlated with health promotion and disease prevention. ${ }^{(6)}$

Occupational disease management and workplace-based health promotion are the ways to build a bridge between the BPJS Kesehatan and the BPJS Ketenagakerjaan to transfer the health care cost proportionally. The occupational health program through workplace health promotion and disease prevention has a potentially high leverage to reduce the financial burden of noncommunicable diseases and malignancy. The other strategic program is transferring the BPJS Kesehatan's financial hardship due to under-diagnosed occupational diseases to the BPJS Ketenagakerjaan. In this case, some approaches to be undertaken include the improvement of occupational diseases management at the levels of health service facilities, policy and regulation, and public education. The primary care physicians and other health professionals should have training on how to identify, diagnose and report occupational diseases along with improvement of equipment and health facilities to support determination of occupational disease causality. It is good to know that there is a new regulation in Presidential Decree No 7 of the year 2019 concerning Occupational Diseases which defines the compensable occupational diseases categories. In addition, the Indonesian Medical Association (IMA) with the Indonesian Occupational Medicine Association and other Indonesian medical specialist organizations just launched the guidelines on occupational diseases management. However, without the policy and regulation as the basis for a clear point of departure of transferring the management of occupational diseases from the BPJS Kesehatan to the BPJS Ketenagakerjaan, the Presidential Decree and the IMA guidelines might be useless. It is equally important to give proper attention to public education about occupational disease identification, diagnosis, and compensation to increase the worker's awareness and participation towards better occupational disease management.

Universal health coverage as part of the National Social Security in Indonesia has been challenging for years in relation to the continuous deficit BPJS Kesehatan has been experiencing. One option to minimize the deficit is to implement comprehensive health care including the occupational medicine and health approach to improve occupational disease management, and noncommunicable disease control and prevention. 


\section{REFERENCES}

1. Ministry of Law and Human Rights, Republic of Indonesia. Act No 24 Of the Year 2011 concerning the social security administrating body. Supplement of the State Gazette of the Republic of Indonesia number 5256.

2. Ministry of National Development Planning. Indonesian health sector review. Jakarta: Kementerian PPN/Bappenas; 2014.

3. Social Security Health Agency. Peserta program JKN per 30 September 2018. Social Security Health Agency/BPJS Kesehatan; 2018.
4. Badan Penyelenggara Jaminan Sosial Ketenegakerjaan. Laporan Keuangan Konsolidasian tahun 2017. Jakarta: BPJS Ketenegakerjaan;2018.

5. Mboi N, Surbakti IM, Trihandini I, et al. On the road to universal health care in Indonesia, 1990 2016: Lancet 2018;392:581-91. doi: 10.1016/S01406736(18)30595-6.

6. Mansyur M. Health finance policy and its impact to the occupational health and safety in Indonesia: Asian-Pacific Newsletter Occup Health Safety 2012;9:48-51. 